3 Sterling, K., Refetoff, S., and Selenkow, H. A., fournal of the American Medical Association, 1970, 213, 571.

- McKenzie, J. M., Fournal of Clinical Endocrinology and Metabolism, $1964,24,660$.

5 Connolly, R. J., Vidor, G. I., and Stewart, J. C., Lancet, 1970, 1, 500.

Hershman, J. M., and Higgins, H. P., New England fournal of Medicine, $1971,284,573$.

7 Crooks, J., Murray, I. P. C., and Wayne, E. J., Quarterly fournal of Medicine, 1959, 28, 211.

${ }^{8}$ Gurney, C., et al., Lancet, 1970, 2, 1275.

- Acland, J. D., fournal of Clinical Pathology, 1971, 24, 187.

Clark, F., and Horn, D. B., Fournal of Clinical Endocrinology and Metabolism, 1965, 25, 39 .

11 Howorth, P. J. N., and MacLagan, N. F., Lancet, 1969, 1, 224.

12 Goolden, A. W. G., Gartside, J. M., and Sanderson, C., Lancet, 1967, 1, 12.

13 Ekins, P. R., Clinica Chimica Acta, 1960, 5, 453.

14 Murphy, B. P., Fournal of Laboratory and Clinical Medicine, 1965, 66, 161.

15 Chan, V., and Landon, J., Lancet, 1972, 1, 4.

16 Sterling, K., and Brenner, M. A., fournal of Clinical Investigation, 1966, $45,153$.

17 Sterling, K., Bellabarba, D., Newman, E. S., and Brenner, M. A., fournal of Clinical Investigation, 1969, 48, 1150 .

18 McKenzie, J. M., Endocrinology, 1958, 63, 372.

19 Ensor, J. M., Kendall-Taylor, P., Munro, D. S., and Smith, B. R., Fournal of Endocrinology, 1971, 49, 487.

Lancet, 1970, 2, 809.

${ }^{21}$ Hershman, J. M., Givens, J. R., Cassidy, C. E., and Astwood, E. B., fournal of Clinical Endocrinology and Metabolism, 1966, 26, 803.

2 Wilson, G. M., in Symposium Thyroid Disease and Calcium Metabolism, p. 51-76. Edinburgh, Royal College of Physicians, 1967
${ }^{23}$ Harden, R. McG., Alexander, W. D., Koutras, D. A., Harrison, M. T., and Wayne, E., Fournal of Clinical Endocrinology and Metabolism, 1966, 26, 397 .

24 Aranow, H., and Day, R. M., fournal of Clinical Endocrinology and Metabolism, 1965, 25, 1

25 Turner, P., Granville-Grossman, K. L., and Smart, J. V., Lancet, 1965, $2,1316$.

26 Shanks, R. G., Hadden, D. R., Lowe, D. C., McDevitt, D. G., and Montgomery, D. A. D., Lancet, 1969, 1, 993.

27 Hadden, D. R., et al., Acta Endocrinologica, 1969, 61, 393.

${ }^{8}$ Hadden, D. R., Montgomery, D. A. D., Shanks, R. G., and Weaver, J. A., Lancet, 1968, 2, 852

${ }^{29}$ Das, G., and Krieger, M., Annals of Internal Medicine, 1969, 70, 985.

30 Riddell, V., British fournal of Surgery, 1962, 48, 291.

31 Hedley, A. J., Flemming, C. J., Chesters, M. I., Michie, W., and Crooks J., British Medical fournal, 1970, 1, 519.

${ }^{2}$ Michie, W., Pegg, C. A. S., and Bewsher, P. D., British Medical fournal, $1972,1,13$.

${ }^{33}$ Irvine, W. J., and Stewart, A. G., in Thyrotoxicosis, ed. W. J. Irvine,

p. 111. Edinburgh and London, E. \& S. Livingstone, 1967.

${ }^{34} \mathrm{McD}$. 11. Eugall, I. R., Kennedy, J. S., and Thomson, J. A., fournal of Clinical Endocrinology and Metabolism, 1971, 33, 287.

35 Pochin, E. E., British Medical fournal, 1960, 2, 1545. 36 Saenger, E. L., Thoma, G. E., and Tompkins, E. A., Fournal of the

37 Nofal, M. M., Beierwaltes, W. H., and Patno, M. E., fournal of the American Medical Association, 1966, 197, 605.

38 Smith, R. N., and Wilson, G. M., British Medical fournal, 1967, 1, 129.

${ }^{9}$ McDougall, I. R., Greig, W. R., and Gillespie, F. C., New England fournal of Medicine, 1971, 285, 1099 .

\title{
Medical Training
}

\section{Survey of Surgical Registrar Promotion in the Birmingham Region 1960-70}

\author{
P. G. BEVAN
}

British Medical fournal, 1972, 2, 341-344

In recent years increasing interest has been shown on all sides in the training content and potential of surgical registrar posts. In all regions Fellowship courses and teaching have been promoted, schemes of rotation initiated, and academic meetings arranged at individual hospitals in increasing numbers. There is a continuing debate on the optimum proportion of training and service in registrar posts, and an annual allowance of study leave is now a recognized part of a registrar's work.

There is surprisingly little information available about the results of this considerable expansion of training activities. Do such courses and rotation schemes still need to be increased, or have we already enough ? Is the training standard of individual posts adequate? Is the proportion of registrars to senior registrars in general surgery still unsatisfactory in providing reasonable promotion chances to the consultant grade? It does not seem possible to answer these questions at present.

To regulate training and decide the right staffing structure it is important to know what has been happening to our surgical trainees-how many have attained consultant status, how many have gone abroad, and how many doctors from abroad come to the United Kingdom for surgical training.

Dudley Road Hospital, Birmingham 18

P. G. BEVAN, CH.M., F.R.C.S., Consultant Surgeon and R.C.S. Regional Adviser in Postgraduate Training in Surgery

\section{Present Study}

In March 1970 the Surgical Registrar Training Committee in the Birmingham region felt the need of precise data on the training of surgical registrars and their career prospects. It was decided to undertake a retrospective survey of the subsequent careers of surgical registrars and senior house officers who had worked in the region during the previous decade.

We report here the result of the survey. The following hospitals supplied statistics, for which we are grateful.

In Birmingham: Accident Hospital; Dudley Road Hospital; East Birmingham Hospital; Good Hope Hospital, Sutton Coldfield; Royal Orthopaedic Hospital; Selly Oak Hospital; and United Birmingham Hospital (General and Queen Elizabeth). Outside Birmingham: Bromsgrove General Hospital; Burton General Hospital; Coventry (Coventry and Warwickshire and the Walsgrave Hospitals); Hereford County Hospital; North Staffordshire Royal Infirmary (Stoke-on-Trent); Shrewsbury (Royal Salop Infirmary); South Warwickshire Group (Leamington-Warneford, Stratford, and Warwick Hospitals); Stafford General Infirmary; Stourbridge (Corbett and Guest Hospitals); Walsall (General and Manor Hospitals); West Bromwich (Hallam and District Hospitals); and Wolverhampton Royal Hospital.

These represent 17 of the 18 hospital groups in the region, including the undergraduate teaching group and two of the specialist hospitals-the Accident and Royal Orthopaedic Hospitals. Although not fully comprehensive most hospitals have been included where general surgical registrars have been employed. 


\section{Results}

The information received is set out in Tables I and II. Of necessity it is incomplete. In many hospitals full records were not kept of posts to which surgical trainees went on leaving; in some cases this was not known or the trainee had no job on leaving. Details sometimes depended on personal memory. The figures returned, however, represent most of the surgical trainees who have worked in the Birmingham region during the past decade and indicate the trend that has obtained. The posts taken by registrars after working in the region are given in Table I and those taken by senior house officers are shown in Table II. There is some duplication as some senior house officers went on to do registrar jobs in the region and thus appear in both tables. The individual trainee's career was followed as far as possible, and only his ultimate known post is entered in the tables. The figures include only trainees in general surgery, orthopaedics, and trauma, and it was not attempted to include the other surgical specialties.

Registrars.-The figures in parenthesis in the "surgery abroad" columns of Table I are posts known to be at consultant grade. The number of consultant posts achieved, both at home and abroad, is probably an understatement as some consultant appointments may have been gained without our knowledge. On the other hand, some trainees may have gone abroad or returned to their own country and not found surgical jobs. Those listed as "qualified in U.K." include nationals from abroad who obtained their medical qualifications in British schools. Most of these returned to their own country to practise surgery after a period of training and passing the F.R.C.S. One special group of registrars worked at the Birmingham Accident Hospital with Mr. P. S. London over a five-year period in the late 1960 s. These were 10 surgical specialists seconded from the Army for six months who then returned to the Army; they are not included in Table I. Registrars in post during or after March 1970 were also not included. Of those unsuccessful in obtaining a post after their registrar job one gave up medicine, one was studying for an English degree in medicine for permanent registration with the aim of doing orthopaedics, and three were unemployed; some of the 14 "not known" may also be in this category, but some may have subsequently obtained surgical posts in both groups.

Senior House Officers. - The numbers in Table II are much smaller than in Table I because there are many fewer senior house officers than registrars in general surgery, orthopaedics, and trauma. Most of the senior house officer posts in the region have been created in recent years, many during the past two years and do not appear in Table II. These posts are of shorter duration than registrar posts and the turnover is more rapid, as senior house officers are usually appointed for six months in the first place and registrars one year. This accounts for the higher proportion of "not known"- $10.3 \%$ in Table II as against $4.7 \%$ in Table I. The proportion of U.K.-qualified trainees is much higher among the senior house officers than the registrars, and the success in gaining further senior house officer or registrar posts at home is striking-44 out of 68 .

Inquiry of Intention. - An inquiry was made of surgical trainees working in hospitals in the region during 1970 about their career aims. This, of course, involved those in post and not appearing in Tables I and II. Only eight hospitals completed this inquiry, and although the numbers are scanty they are shown in Table III. In most hospitals it was taken for granted that surgical registrars and senior house officers in post intended to continue with surgery as their permanent career. This is certainly borne out by the 58 answers in Table III, as only one

TABLE I-Surgical Registrar Appointments in the Birmingham Region 1960-70

\begin{tabular}{|c|c|c|c|c|c|c|c|c|c|c|c|c|c|}
\hline \multirow{2}{*}{\multicolumn{2}{|c|}{ Hospital }} & \multirow[b]{2}{*}{ Total } & \multicolumn{2}{|c|}{ Qualified } & \multirow{2}{*}{\begin{tabular}{|c|} 
Consultant \\
Post \\
U.K.
\end{tabular}} & \multirow{2}{*}{$\begin{array}{c}\text { Senior } \\
\text { Registrar } \\
\text { Post } \\
\text { U.K. }\end{array}$} & \multirow{2}{*}{$\begin{array}{c}\text { Registrar } \\
\text { Post } \\
\text { U.K. }\end{array}$} & \multicolumn{2}{|c|}{ Surgery Abroad* } & \multirow{2}{*}{$\begin{array}{l}\text { General } \\
\text { Practice }\end{array}$} & \multirow{2}{*}{$\begin{array}{l}\text { Specialty Other } \\
\text { than Surgery }\end{array}$} & \multirow{2}{*}{$\underset{\text { Known }}{\text { Not }}$} & \multirow[b]{2}{*}{ Unplaced } \\
\hline & & & U.K. & Abroad & & & & $\begin{array}{l}\text { Own } \\
\text { Country }\end{array}$ & $\begin{array}{l}\text { New } \\
\text { Country }\end{array}$ & & & & \\
\hline $\begin{array}{l}\text { In Birmingham } \\
\text { Accident } \\
\text { Dudley Road } \\
\text { East Birmingham } \\
\text { Good Hope.. } \\
\text { Royal Orthopaedic. } \\
\text { Selly Oak .. } \\
\text { United Birminghan } \\
\text { Outside Birmingham } \\
\text { Bromsgrove } \\
\text { Burton } \\
\text { Coventry .. } \\
\text { Hereford .. } \\
\text { Shrewsbury } \\
\text { South Warwicks } \\
\text { Stafford .. } \\
\text { Stoke: } \\
\text { General ... } \\
\text { Orthopaedic } \\
\text { Neurosurgical } \\
\text { Thoracic } \\
\text { Stourbridge } \\
\text { Walsall . } \\
\text { West Bromwich } \\
\text { Wolverhampton }\end{array}$ & 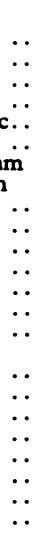 & $\begin{array}{r}24 \\
8 \\
14 \\
3 \\
23 \\
24 \\
53 \\
8 \\
8 \\
7 \\
16 \\
11 \\
7 \\
12 \\
12 \\
11 \\
16 \\
6 \\
5 \\
14 \\
4 \\
6 \\
12\end{array}$ & $\begin{array}{r}14 \\
6 \\
5 \\
1 \\
11 \\
14 \\
50 \\
1 \\
1 \\
2 \\
3 \\
4 \\
4 \\
6 \\
4 \\
5 \\
2 \\
2 \\
6 \\
1 \\
3 \\
9\end{array}$ & $\begin{array}{r}10 \\
2 \\
9 \\
2 \\
12 \\
10 \\
3 \\
7 \\
7 \\
5 \\
13 \\
7 \\
3 \\
6 \\
8 \\
6 \\
14 \\
6 \\
3 \\
8 \\
3 \\
3 \\
3\end{array}$ & $\begin{array}{l}3 \\
1 \\
2 \\
1 \\
1 \\
9\end{array}$ & $\begin{array}{r}4 \\
4 \\
1 \\
8 \\
3 \\
17 \\
1 \\
1 \\
2 \\
1 \\
1\end{array}$ & $\begin{array}{r}3 \\
2 \\
3 \\
2 \\
4 \\
10 \\
17 \\
2 \\
1 \\
1 \\
1 \\
1 \\
4 \\
2 \\
4 \\
2 \\
2 \\
1 \\
3 \\
1 \\
1 \\
5\end{array}$ & $\begin{array}{c}10(6) \\
1 \\
5 \\
9(5) \\
6(1) \\
\\
5(4) \\
2(1) \\
11(2) \\
6(2) \\
1 \\
7 \\
4(2) \\
3 \\
4 \\
1(1) \\
2(2) \\
4 \\
1(1) \\
1 \\
1(1)\end{array}$ & $\begin{array}{l}1 \\
1 \\
2 \\
2(1) \\
1 \\
1 \\
2\end{array}$ & $\begin{array}{c}1 \\
4 \\
2 \text { (1 med. asst.) } \\
4 \\
1\end{array}$ & 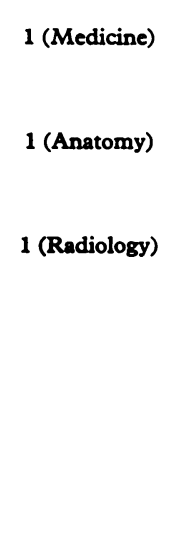 & $\begin{array}{l}1 \\
2\end{array}$ & $\begin{array}{l}1 \\
1 \\
1\end{array}$ \\
\hline Total $\quad \ldots$ & $\ldots$ & 296 & 153 & 143 & 26 & 54 & 72 & 84 & 20 & 18 & 3 & 14 & 5 \\
\hline
\end{tabular}

- Figures in parentheses refer to appointments known to be at consultant grade.

TABLE II-Senior House Officer Appointments in Surgery; Birmingham Region 1960-70

\begin{tabular}{|c|c|c|c|c|c|c|c|c|c|}
\hline \multirow{2}{*}{ Hospital } & \multirow{2}{*}{ Total } & \multicolumn{2}{|c|}{ Qualified } & \multirow{2}{*}{$\begin{array}{c}\text { Senior Surgical } \\
\text { Registrar } \\
\text { U.K. } \\
\end{array}$} & \multirow{2}{*}{$\begin{array}{c}\text { Registrar or } \\
\text { Senior House } \\
\text { Officer U.K. }\end{array}$} & \multicolumn{2}{|c|}{ Surgery Abroad } & \multirow{2}{*}{$\begin{array}{l}\text { General } \\
\text { Practice }\end{array}$} & \multirow{2}{*}{ Not Known } \\
\hline & & U.K. & Abroad & & & Own Country & New Country & & \\
\hline $\begin{array}{l}\text { In Birmingham } \\
\text { Accident } \\
\text { Dudley Road } \\
\text { Good Hope... } \\
\text { Royal Orthopaedic } \\
\text { United Birmingham. } \\
\text { Outside Birmingham } \\
\text { Burton } \quad . \\
\text { Hereford } \\
\text { West Bromwich }\end{array}$ & $\begin{array}{r}8 \\
6 \\
11 \\
9 \\
16 \\
10 \\
2 \\
6\end{array}$ & $\begin{array}{r}7 \\
3 \\
4 \\
0 \\
16 \\
5 \\
1 \\
5\end{array}$ & $\begin{array}{l}1 \\
3 \\
7 \\
9 \\
0 \\
5 \\
1 \\
1\end{array}$ & 3 & $\begin{array}{r}5 \\
2 \\
4 \\
7 \\
14 \\
5 \\
1 \\
3\end{array}$ & $\begin{array}{l}2 \\
5 \\
2 \\
\\
2\end{array}$ & $\begin{array}{l}1 \\
2 \\
\end{array}$ & $\begin{array}{l}1 \\
1\end{array}$ & $\begin{array}{l}1 \\
1 \\
2 \\
2 \\
1\end{array}$ \\
\hline Total & 68 & 41 & 27 & 3 & 41 & 11 & 3 & 3 & 7 \\
\hline
\end{tabular}


TABLE III-Inquiry of Intention

\begin{tabular}{|c|c|c|c|c|c|c|}
\hline \multirow{2}{*}{\multicolumn{2}{|c|}{ Hospital }} & \multirow{3}{*}{$\begin{array}{c}\text { Registrars } \\
3 \\
2 \\
1 \\
4\end{array}$} & \multirow{3}{*}{$\begin{array}{c}\text { Senior } \\
\text { House } \\
\text { Officers } \\
3 \\
6 \\
3 \\
2 \\
4\end{array}$} & \multicolumn{2}{|c|}{ Qualified } & Intention \\
\hline & & & & & & \\
\hline 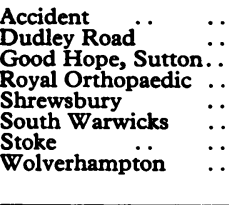 & $\begin{array}{l}\because \\
\because \\
\because \\
\because \\
\therefore \\
\cdots\end{array}$ & & & $\begin{array}{r}4 \\
2 \\
3 \\
4 \\
13\end{array}$ & $\begin{array}{l}4 \\
4 \\
4 \\
4 \\
1 \\
5 \\
4\end{array}$ & $\begin{array}{l}2 \text { General surgery, } 3 \text { orthopaedics, } 1 \text { plastic surgery } \\
4 \text { General surgery U.K.; } 4 \text { English F.R.C.S., return India } \\
4 \text { English F.R.C.S., return home } \\
3 \text { Senior surgical registrar U.K., } 3 \text { return home } \\
3 \text { English F.R.C.S., return home; 1 uncertain } \\
2 \text { Surgery U.K., } 1 \text { primary F.R.C.S., } 1 \text { return Australia } \\
4 \text { Surgery U.K. } 3 \text { general, 1 urology); } 4 \text { surgery, return home; } 1 \text { surgery new country } \\
13 \text { Surgery U.K. (4 general, } 5 \text { orthopaedic, } 2 \text { plastic, } 2 \text { urology), } 2 \text { surgery abroad, } \\
1 \text { farming, } 1 \text { not known }\end{array}$ \\
\hline Total $\quad$. & .. & 40 & 18 & 26 & 26 & \\
\hline
\end{tabular}

admitted the intention of giving up surgery, although there was one "not known." Of the $18(6 \cdot 1 \%)$ registrars and senior house officers who entered general practice (Tables I and II) 15 were placed in England and 3 went abroad (including one British graduate); none of the 15 general practitioners in England had expressed the intention of doing general practice but went into this field because of failing the F.R.C.S., failing to get a further surgical job, or because a good post in general practice presented. Eleven of these 18 were doctors from abroad and seven qualified in the U.K.

\section{Discussion}

This survey suffers from the defects of all retrospective studies and is not complete or comprehensive. Nevertheless, the number of surgical trainees authenticated and included shows a general pattern which is of interest and value. This pattern may well be individual for the Birmingham region, and other regions, especially the Metropolitan, would probably show quite different results.

The overall picture that emerges gives rise to some satisfaction, in so far as the Birmingham region has supplied many registrars with valuable training and experience and has helped most of them on their way to the completion of their surgical careers. Out of 296 registrars studied (Table I) $26(8.8 \%)$ had already obtained consultant posts at home by the time the survey was completed and $54(18.3 \%)$ had obtained senior surgical registrarships at home, of whom virtually all would become consultants in this country.

There were two main streams of trainees. Graduates of British medical schools have succeeded in gaining senior registrar or consultant posts in the United Kingdom, as mentioned above, the majority in the region where they did their registrar jobs. Of the 26 registrars reaching consultant status in Britain 24 were British graduates; 13 of these were Birmingham graduates gaining consultant appointments in the Birmingham region. Of the 54 registrars gaining senior registrar appointments in Britain 48 were British graduates; 18 Birmingham graduates were appointed senior surgical registrars in the Birmingham region. These figures underline the valuable part played by the Birmingham region in training and providing adequate promotion for surgical trainees qualifying in Britain and the Midlands. Most of these registrars have obtained senior registrar posts in the field of their choice (either general surgery or orthopaedics). A few have "side-stepped" from general surgery into other specialties-urology, plastic surgery, neurosurgery, trauma, and paediatric surgery.

Adequate room has been made for graduates from other schools in Britain to obtain surgical registrar posts in the Birmingham region, and inter-regional movement is of great importance in surgical training. By informal arrangement graduates of St. Thomas's Hospital, London, have done registrar jobs at Wolverhampton Royal Hospital and in the South Warwickshire Group. Similar schemes should be encouraged wherever possible between regions to prevent inbreeding.
The second group consists of graduates from abroad and in the main is composed of those from the subcontinent of India, tropical Africa, the Middle East, and South Africa, as well as from Australia, New Zealand, and Canada. Most have worked in the region in the registrar grade and many have passed the F.R.C.S. Subsequently most have returned to surgical posts in their own country, with a few finding surgical careers in new countries. Only $5.7 \%$ of the registrars in the United Birmingham Hospitals were recruited from this group, although this does not take into account the numerous locums, research fellows, and those doing supernumerary attachment posts from abroad who have had the opportunity of experience at the undergraduate teaching hospitals. Altogether $60.2 \%$ (118 out of 196) of the registrars working in the district general hospitals were from abroad. Of the 143 registrars from abroad who worked in the Birmingham region $84(58 \cdot 7 \%)$ returned to do surgery in their own country, and of these it is known that 28 obtained posts at a consultant grade or the equivalent, this being a minimum figure. This represents a considerable contribution by the Birmingham region to the training of surgeons from abroad who return to work in their own countries. The 20 registrars who left England to work in new countries include some of our own graduates as well as those from abroad and represent only $6.8 \%$ of the whole.

The figures from the Birmingham Accident and Royal Orthopaedic Hospitals illustrate the unique contribution made by the specialist hospitals to surgical training in their own specialties. They show a high success rate in supplying senior registrars and consultants in Britain, as well as training personnel from abroad who then return to consultant posts in their own country. Out of 47 registrars working at these two hospitals four obtained consultant posts in the United Kingdom, 11 consultant posts abroad, and 12 senior surgical registrar posts in the United Kingdom during the period of the survey.

The total fall-out ratio was low. Only $1.7 \%$ of the registrars were known to be unplaced, though this is a minimum figure as the subsequent careers of $4.7 \%$ were not known. Altogether $6.1 \%$ of the registrars went into general practice and only three entered specialties in medicine outside surgery. This gives a total fall-out of 26 out of $296(8.8 \%)$, with 14 (4.7\%) not known.

The main problem found by the survey concerns doctors from abroad who come to Britain to pass the F.R.C.S. and receive training and experience in surgery at the registrar level. There are not the posts available for most of them to work at the undergraduate teaching hospitals. They have also found difficulty in obtaining further posts after their first senior house officer or registrar post in district general hospitals and have had to sidestep into a different branch of surgery or move to another region in rather a haphazard way. As they make a valuable contribution to British surgery, particularly in peripheral hospitals, thought must be given to improve this situation.

Surgical trainees from abroad need to have a satisfactory training programme worked out for them for a restricted number of years to enable them to pass the F.R.C.S. and gain experience that will qualify them to return as consultant surgeons to their own country. This survey shows that this group of surgical trainees has little chance of gaining senior surgical appoint- 
ments in Britain, as the establishment of this pre-consultant grade is sufficient only for graduates of British schools. Britain's entry into Europe will make it even more urgent to design a training ladder with its own defined grades and time periods for graduates from abroad. Another side to this problem is the difficulty of most peripheral hospitals in attracting British graduates as senior house officers and registrars, and methods of redressing this balance must be found.

This survey has yielded much helpful and interesting information and yet suffers from being retrospective. It underlines the importance of developing an adequate system of records for the details of surgical trainees' careers throughout the region and keeping in touch with them. A central agency in Birmingham for this purpose is worthy of consideration. As exact data about registrars' careers are necessary to guide training and regulate staffing a prospective survey for the next five years is being started.

The idea of this survey resulted from a conversation with $\mathrm{Mr}$. L. D. Abrams. I should like to thank the following for their help in providing statistics: Professor G. Slaney, Messrs. P. L. Berger, J. E. Bridger, J. H. Bulmer, A. Clain, J. M. Dolphin, J. G. Gray, J. D. Hennessey, D. Lincoln Lewis, P. S. London, J. D. Marsh, E. J. Newton, D. J. Oakland, H. Piggott, B. H. Price, A. Rhodes, J. M. Sanderson, Irvine B. Smith, D. Tooms, R. W. Tudor, and G. T. Watts.

ADDENDUM.-Since submission of the manuscript the survey has been completed by statistics from Worcester Royal Infirmary by Mr. C. P. Nicholas. Seventeen surgical registrars are included who worked at Worcester during the period of the survey. All qualified abroad, 11 in India. Eleven passed the F.R.C.S. while in post at Worcester. Eight returned to their own country to do surgery, and five of these obtained consultant posts. Four gained surgical posts abroad in a new country, three at consultant level. Four were appointed to registrar jobs in the U.K. and the subsequent appointment of the remaining registrar is not known.

\section{Any Questions?}

We publish below a selection of questions and answers of general interest

\section{Sulphur Burns}

What is the first-aid treatment for burns caused by molten sulphur in an industrial environment?

Burns caused by molten sulphur are unusual in the United Kingdom, but we have experience with other molten materials such as tar or bitumen. First aid treatment should not differ greatly from that given for any burn. To prevent bacterial contamination of the burned area the burn should be covered with a temporary sterile dressing such as gauze and cotton wool held in place by a crepe bandage. If a sterile dressing is not available freshly-laundered linen may be used, and the patient is then taken to see the doctor who would then decide on definitive treatment. ${ }^{1}$

In the case of extensive burns (bigger than $15 \%$ of the area of the body) a simple method should be used so that the patient can be taken quickly to hospital for urgent intravenous plasma transfusion. Sterile or freshly laundered sheets are useful in these larger cases; the patient can be rapidly put into the sheet and transferred to hospital. ${ }^{2}$ If the molten material is adherent to the burned area and is still hot immersion of the affected area in cold water is essential to prevent a deeper burn. For this purpose showers or other means of cold water supply should be readily available. ${ }^{3}$

Organic solvents, such as carbon bisulphide should not be used to remove the sulphur because of the danger of toxic absorption through the skin.

1 Cason, J. S., Advanced First Aid, No. 4, First Aid Treatment for Burned Patients. London, Camera Talks Limited, 1963.

2 Proctor, H., and London, P. S., Principles for First Aid for the Injured, 2nd edn. London, Butterworths, 1968.

3 Colson, P., and Biron, G., in Encyclopaedia of Occupational Health and Safety, Vol. 1. Geneva, International Labour Office, 1971.

\section{Blount's Disease}

What is Blount's disease, and how should it be treated?

This is an exceedingly rare condition. From about two years of age an affected child develops a progressive bow-legged deformity which may involve one or both sides and is generally associated with an internal torsion and deformity of the tibia. The cause is unknown but there is an abnormality present on the inner side on the upper tibial epiphysis. In the very young a corrective osteotomy should be performed and this will often result in preventing further deformity as frequently it is followed by healing of the lesion. In some it continues and further operation is necessary. The disease occasionally arises in older children, when the prognosis is better.

1 Golding, J. S. R., and McNeil, J. D. G., fournal of Bone and foint Surgery, 1963, 45B, 320.

\section{Brucellosis Treatment}

A recommended treatment for brucellosis is three 4-week courses of Septrin separated by intervals of two weeks. What is the rationale of this and is it any better than a continuous course of treatment?

Results of trimethroprim-sulphonamide treatment of acute infections with Brucella abortus or Brucella melitensis have been very encouraging. ${ }^{1-4}$ Treatment has resulted in prompt defervescence of symptoms usually within the first 48 hours and normal temperatures within the first week. The optimum regimen is, however, far from settled. For example, Giunchi et al. ${ }^{4}$ used different regimens for each of their nine patients and recommend one which was not used in any. Patients have been treated without subsequent relapse with as little as two tablets 12-hourly for 10 days, but general experience suggests that relapse is likely to occur with courses of less than three weeks. The choice lies between more prolonged, or repeated treatment. There is no reason to believe that gaps in therapy are beneficial, but it seems reasonable on the basis of the present evidence to treat adults with two tablets 12-hourly for four weeks and to retreat for similar periods if necessary.

1 Lal, S., Modawal, K. K., Fowle, A. S. E., Peach, B., and Popham, R. D., British Medical' Fournal, $1970,3,256$.

2 R. D., British Medical Wournal, M. F. A., Sanborn, W. R., and Kent, D. Z., Hassan, A., Wahab, M. F. A., Sanbor

D. C., British Medical Fournal, 1970. 3, 323. S. D., and Sorensen, K., British Medical Fournal, 1973, 3, 159.

4 Giunchi, G., de Rosa, F., and Fabiani, F., Chemotherapy, 1971, 16, 332. 